\title{
Plays of Henrik Ibsen on the Albanian Stage
}

\author{
Dr. Rregjina Gokaj \\ University "Aleksandër Moisiu" Durrës, Albania \\ E-mail: rregjinagokaj@gmail.com
}

\section{Doi:10.5901/jesr.2014.v4n6p535}

\begin{abstract}
This paper mainly focuses on the Ibsen's plays staged on the Albanian Theatre through the years. It mainly picks out the most famous plays of Ibsen, such as "An Enemy to the People", "A Doll's House" and "John Gabriel Borkman". The Albanian audience through the translation of Noli knows Henrik Ibsen, so the stage directors made their exquisite choices while deciding to put his plays on Albanian National Theatre, but not only. The cast of the actors managed to transmit Ibsen's most notorious ideas of modern drama, his drama of ideas also called discussion dramas. A special feature of Ibsen's dramas was not the events, but the characters. Each character is personalized, clearly drawn within some unexplored psychic targets; it is a strong "solitary", hardly manipulated, almost a pre-destined one, acting, and fitting itself to a hereditary condition, suddenly found in the panic of an increasing pressure that tends to cover or to bypass a terrifying secret. Its soul formula is irreparable. This was the motto of the actors while staging Ibsen's plays under the directions of the talented directors.
\end{abstract}

\section{Ibsen and His Plays}

Henrik Ibsen (1828-1906) is a known author for the Albanian theater. He initially became famous in the Albanian library thanks to the brilliant translation of his play "An Enemy of the People" by F. Noli, accompanied by his clever remarks through the Introduction part, with fine analysis on philosophical background as well. In the 60s and later on (in the 80s), the Albanian reader had the chance to meet Ibsen again with two editions of his plays in Albanian language By selecting mainly social dramas, other important Ibsen's dramas are not translated yet even though they carry symbolic and psychoanalytic values.

Early engaged with the Norwegian National Theatre in Bergen, he adapted for stage about 145 works and wrote 25 plays; he was also the director of theater and, often at times, even a stage director. His work exerted a great influence on drama and theater throughout Europe. Ibsen became famous with the so-called "drama of ideas", a sort of " discussion drama " with radical solutions to conflicts (we can pick here "An Enemy of the People", "Pillars of Society", "A Doll House", "Ghosts", "Hedda Gabler"), with the symbolic strings and trends (we can pick here "Wild Duck "," Rosmersholm "," The Lady from the Sea ","John Gabriel Borkman"," When We Dead Awaken","Little Eyolf'). Ibsen experimented verse drama, which were inspired by the past of Scandinavia (we can pick here "Lady Inger of Oestraat", "The Pretenders"), especially two dramatic poems, "Brand" and "Peer Gynt". The first in line centers the figure of the idealist who seeks to overthrow the society from decadence, from corruption and dirty compromises; to free man and the society from sin and the shackles of circumstances; to lead him towards a pure and free soul, sacrificing everything. The second centers the figure of the adventurous man, which makes his best to avoid any of the problems faced with, any of the duties and responsibilities that fall on him, wandering around the world pulled by greedy voracity in search of absolute freedom and fantasy.

A special feature of Ibsen's dramas was not the events, but the characters. Each character is personalized, clearly drawn within some unexplored psychic targets; it is a strong "solitary", hardly manipulated, almost a pre-destined one, acting and fitting itself to a hereditary condition, suddenly found in the panic of an increasing pressure that tends to cover or to bypass a terrifying secret. Its soul formula is irreparable. Usually the characters of Ibsen move (attack or defend) because of oppressed psychic impulses that secretly lie nestled somewhere in the traumatized subconscious, which turn up to become internal, essential and existential motifs, gradually embracing the whole character completely. Mostly, his characters' psyche appears in the form of a prolonged suffering, slow at the beginning then furiously towards a dramatic devastating experience. The illusory, unperturbed status, as a prolonged and false peace, is abruptly cut off in two from the sudden discovery of a secret kept for years; this same secret which becomes a languidness and destruction, as happens with the drama "Wild Duck", put on stage by students of Arts Academy in the late 90s. Verles Greger, a utopian moralist, seeks to destroy the illusions upon which the happiness of a simple family is built; but rather than solving the 
problem, he confuses it for worse; rather than bringing joy and prosperity, he brings destruction and calamity. He reveals the causes of a former tragedy, that time had set aside; but now, being reactivated it becomes shattering and disrupts that false "state of peace", which consoled and made this family members feel happy. The young actors specifically brought this very unhealthy atmosphere, this crippling alienation, this double foul illusion on stage.

Such contrasts as in the "Wild Duck", but in another sense, are also noted in "Pillars of Society", where Bernick, initially is presented as the "champion" of social morality and as suitor of law, but actually it turns out that he himself was a vicious man once. So to say, his claim falls headlong dive. What is immoral becomes moral, what is translucent becomes opaque. According to Ibsen, politics and society cannot be built on fraud and vices; a group of people with a sinful and hidden suspicious past also cannot build it. This overpass from a state to another, apart from the direct destructive effect on the protagonist (and supporters), leads us to assume, on the other hand, their prolonged spiritual toils. The characters of Ibsen intensively experience the "unseen" part of them; even though neither do the readers nor does the audience understand them from the very beginning. The "hidden" comes out as an inner fear, as an inflammatory situation, as prolonged psychological pressure, which eventually turns out into a personal disaster.

Symbolism gained space time after time in Ibsen's works, especially in his last ones, where he doubles or multiplies the semantics that comes out of the flow of events and the destiny of the characters. There the writer lays in different levels his ideas, pictures, additional access, which gains a different meaning or is alternated. Usually they become associative and figurative metaphors, real ones that carry a clear ideological independence. The Wild Duck, which floats and bathes itself in a washtub somewhere in the basement, it gets the sense of freedom that man lacks, the same way as that of the acclimatization, of the transfiguration, of the isolation or confinement. In "Rosmersholm", the symbol of the White Horse is transformed into the metaphor of concern, the force of the mystery of the situation, same as the clouds of mountains exercise an irresistible attraction, like a fatal and mysterious gravity in "When We Dead Awaken".

Considering "Ghosts", we can notice that the symbol is associated with a prolonged trauma and implied revenge, that dwells together in the love and motherhood of Lady Alvig, who has been hiding for years a shame her former husband, who suffered from syphilis. The son becomes the victim of his father's past, which follows him like a ghost and a curse. Lady Alvig is destroyed, as well. This drama was presented in several versions in the Albanian theater to the audience. The beauty or the virtuous cannot clean up the corrupt past, infected not only by diseases (physiological and psychological); but also by a betrayed marriage. This betrayed marriage turns into a real nightmare because of the incest between brother and sister, and it ends up in a death warning. Such highlights coming from Ibsen's dramas have also been transmitted to the Albanian public through its staging.

\section{Ibsen on Stage - Speaking Albanian}

"John Gabriel Borkman" was staged by young actors studio of the Albanian National Theatre in 1979, where the problem was the freedom of choice to be against tutelage and a conservative upbringing, to camouflage selfishness, false pride and self delusion, it was combined with climate and failing human suffocating in an atmosphere of greed and alienation. "Most of the characters in "John Gabriel Borkman" are alive-dead ones, they are dead bodies breathing, walking, weaving dialogues and monologues although their way of life is over, although all of them are "ex-es", but they do not want to believe it... "- Bashkim Shehu notes in the publication foreword of the play in Albanian.

This idea was demonstrated through the young actors studio of Youth National Theatre, raised on its both planes: first, the treatment of John Gabriel Borkman as an "ex" of projects once powerful and now abandoned and besieged, and second the irony of his earlier relations with both "sisters": Mrs. Borkman and Ela Rent Heiner. These two affairs of Borkman consisted mainly on interest basis (Mrs. Borkman) and on one-side love comforter to death (Ela).

The stage acting of the actors permits to bring death as a present substrate everywhere, consider it a physical death, or as allegorical death, or as a symbolic one. The partially physical death of Borkman at the end of the play alternates with the total death of a way of thinking and living. Thus, the public categorized the overall death allegory first as comprehensive spiritual death, as loss or wastage of the ideal, of the dream, of the youth; and further as abandonment, as time set, as life wasted through greed and empty glories, and hidden selfishness.

One of the most prominent theatrical realizations of Ibsen's plays, is undoubtedly "A Doll's House" staged in the early year of 1963 in Migjeni Theatre (Shkodër) from the well known Albanian stage director Esat Oktrova. The break of the marriage, the rebellion and Nora's escape from home and Hailmar's tutelage was a challenge for the Albanian audience at that time. We can notice that the action itself was more an illuminist one than a bourgeois one. Nora's rebellion resembled with a pure moral act, even though it was strongly considered as a step forward the society's 
development of the time. The emancipation of the woman was considered not only in the relations between husband and wife, but it was knotted in the relation mother and child as well as father and daughter. Through Nora, Ibsen tried to make us understand the real dimensions a woman can have - once understood by the actors, this idea has to be transmitted to the audience the same. This was made possible through the devotion of the stage director Oktrova while working with talented actors and actresses of the time. Nora was played by the famous Albanian actress Tinka Kurti, who knew at her best what being a mother and a wife at that time meant. Ibsen tried to flatter Nora's role at the beginning as a nonchalant, skittish doll, full of coquetries and flummeries; who never cared about anything but the husband has to control and take decisions for the family. The "Nora" of Tinka Kurti was more or less an Albanian woman carrying the same virtues o the wife but less flattered from the Albanian husbands. Ibsen's Nora was decades ahead Kurti's Nora chronologically, but the feelings flickering of both Nora-s were apprehensible form the Albanian audience of the 60s, especially when it comes to humiliation or insulting the dignity.

The critique of the time notes: "the audience evaluates not only the way how actors win public's scorn for Torvald, but also the audience wins an evaluation for those women who persist in their human rights and equality to men; but it also preserves a great disdain for al those men who still preserve in their conscious the preponderance over women." Of course this was an "official" finding of the critique of that time, covered by a moralizing cloth which originates from the propaganda, because the real truth about the man - woman relations was mostly of masculine predominance. In Europe, we can notice that Nora became a symbol of the feminist movement at the beginning of the twentieth century; Nora was a conceptual approach modeled more or less like a consciousness; like a pure intention of how far should this movement go and what it would further require in relation to place, country, rights, family ties and meaning of love. This play staged in Migjeni Theatre in Shkodra rightly asked: what are the moral principles upon which the right and the personality affirmation of women in society should be raised in Albania, where the society was mainly dominated by masculine principles? In the directorial concept of Esat Oktrova, as well as in the actors' play there were clearly noticed out two points, which are considered essentially contrapuntal: firstly, hiding or skipping of what was happening in Torvald's family; and secondly, Nora's abrupt and irrevocable decision to leave the family in search of herself. According to Oktrova, Ibsen's Nora by Tinka Kurti could not be just a coquette for her husband, but mainly a worthy educator for her children, a woman who asked for her own respect and dignity in the family and equal rights in society. ${ }^{2}$

"You know that Ibsen's Nora was turned into the metaphor of the general movement for the emancipation of the woman in Europe but not only, - E. Oktrova notices, - that's why it was not easy for my directorial concept to give the heroine and the brave woman on one hand, and the pampered and conceited woman, devoted to family and children within her tiny world, on the other hand. These are two different, apparently opposite planes, which might be excluding as well. What I wanted to offer to the audience was exactly the complexity, the turbidity, and the spiritual contradict of Nora made possible through the passionate interpretation of Tinka Kurti"3

\section{3. "An Enemy to the People" - This Prophecy of Time!}

One of the most powerful plays Ibsen ever wrote, whose sharp blant of political and social problems soak one's sight, is "An Enemy to the People". Ibsen wrote this play in 1882 and the wit Albanian translator Fan Noli picked this out to give it into Albanian accompanied with a witty "Introduction". "World theatre, be it Ancient or Modern, lacks another play like this which mocks deeply and beautifully the bourgeois ideals, pretended to be democratic ones - Noli stresses in his Introduction to the play- ... No, Sir! The bourgeois world does have only one ideal, which it worships like a God, which is: Plunder at any cost. Who plunders more is considered as most ace or the Greatest..."4

The director Agim Qirjaqi put this play on stage in 2000 in the Albanian National Theatre. "An Enemy to the People" shook the theatre from the prolonged lethargic sleep. It gave another view, as well as a different level separating itself from the jerk of lacking choices. The play gained success because of Ibsen's text, first; this fiery apology of the human personality and civil society in general where the new generations yearn to go. Another success was because of the stage director and his cast who gave a very profound taste of foreign drama on the Albanian stage.

\footnotetext{
${ }^{1}$ Bala, Vebi. "Nora e Ibsenit në teatrin e Shkodrës", "Zëri i Popullit".

2 See: Oktrova Esat. Përvoja e regjisorit në teatër, Tiranë, 2002.

${ }^{3}$ An interview with the well known Albanian director Esat Oktrova, realized from Josif Papagjoni. Archive, QSA.

${ }^{4}$ F. S. Noli, "Introduktë për dramën e Ibsenit "Armiku i Popullit", Henrik Ibsen, Drama, Sh. B. "Naim Frashëri", 1986 and the Flyer of the Play "An Enemy to the People". National Theatre. Tiranë, 2000.
} 


\section{Casting - among Ibsen and Albanians}

One of the most important pillars where the play "An Enemy to the People" had its major role was the interpretation full of passion of the actors and directorial mind power of Agim Qirjaqi. The roles were like a gallery of characters, which were artistically transmitted through actors like Fatos Sela (Dr. Stockmann), Bujar Asqeriu (Hosvald), Agim Qirjaqi (Aslaksen), Ahmet Pasha (Peter Stockmann) etc. it is easily noticed an obvious compatibility of features, data, simulations; far to the way they look, the way they behave and their noble faces, to quietness and wise word authority, to sincerity, to conviction between what is expressed and what is targeted, to the closeness of the actor with the role.

The mocking tones of the dialogue, especially in Act IV, seemed as they enlightened the noble and brave character, as they extolled it to the glory while underestimating the false "power" of this "brainless, heartless drove" - as Noli would say in his introduction to the play. Then we come to Hosvald of Bujar Asqeriu, a painted intellectual who declares himself as the "protector of the people"; who indeed is a one more lickspittle and nothing else. Asqeriu made himself notable with his outbursts, welter of impetuous emotions that provoked his temper and offended self-respect. Asqeriu managed to draft the representative of the "militancy" erected from the catacombs, as a servile, unstable, and miserable man. If we consider Aslaksen of Agim Qirjaqi, as a bad tutor of the "compact mass" that rots the rebel souls, the actor managed to show the double face of small-minded people, who bare a distorted personality because of the lack of courage, honesty, and dignity. Ahmet Pasha acting the character of Peter Stockmann gives us the security of the man, who shows himself as a prepotent, a business-executive, a slave of party "constitutions", an emissary of the status-quo; a character already undone from the arrogance, cynicism, and the lack of self thought. We have to applause also the character of the journalist staged by Sokol Angjeli. The freedom of acting and satirizing the whole escort of extremists, radicals and anarchists who follow the social and political turmoil meets the expectations of Ibsen's idea for such a character. Praise goes to the cast of minor characters staged with love and passion from Luiza Xhuvani (as Petra Stockmann), Guljem Radoja (as Captain Horster), Pavlina Mani (as Katherine) etc., where the whole cast of the Albanian National Theatre realized the famous quote of Stanislavsky: "Remember: there are no small parts or great parts, only small or great actors in small or great parts." 5

All these actors played within the parameters of the emotional side mainly. this meant the same with the spiritual state of each respective active and character of the play, with their targets, with their behavior, with the concrete relation that they themselves have set among the events of the play, with the conflict of the play, with other characters standing against or pro this conflict. So, essentially we had the mere form of the sensor identification of the cast with the respective roles and characters, so that anyone could intend to transform himself or herself into a direct host of the soul situation of this or that role part, in the same line with the all-embracing dramatic action given by Ibsen, the author himself. This acting "style", this acting mood, already known and widely applicable for decades in many theatres around the world, found ground even on the Albanian stage as an achievement of what is called "Platonic Quote" of the evocation of the actor on stage. We have to admit that the play "An Enemy to the People" reached the most valuable levels realized within the last decade in the Albanian Theatre, considering it as the ensemble of actors. Apart from success, we have to notice that the directors should be somehow blamed of is the lack of Ibsen's plays on Albanian stages those years.

\section{References}

An interview with the well known Albanian director Esat Oktrova, realized from Josif Papagjoni. Archive, QSA.

Bala, Vebi. "Nora e Ibsenit në teatrin e Shkodrës", "Zëri i Popullit".

F. S. Noli, "Introduktë për dramën e Ibsenit "Armiku i Popullit", Henrik Ibsen, Drama, Sh. B. "Naim Frashëri", 1986 and the Flyer of the Play "An Enemy to the People". National Theatre. Tiranë, 2000.

Oktrova Esat. Përvoja e regjisorit në teatër, Tiranë, 2002.

Constantin Stanislavski. (n.d.). BrainyQuote.com. Retrieved October 6, 2014, from BrainyQuote.com Web site: http://www.brainyquote.com/quotes/authors/c/constantin_stanislavski.html

5 Constantin Stanislavski. (n.d.). BrainyQuote.com. Retrieved October 6, 2014, from BrainyQuote.com Web site: http://www.brainyquote.com/quotes/authors/c/constantin_stanislavski.html 